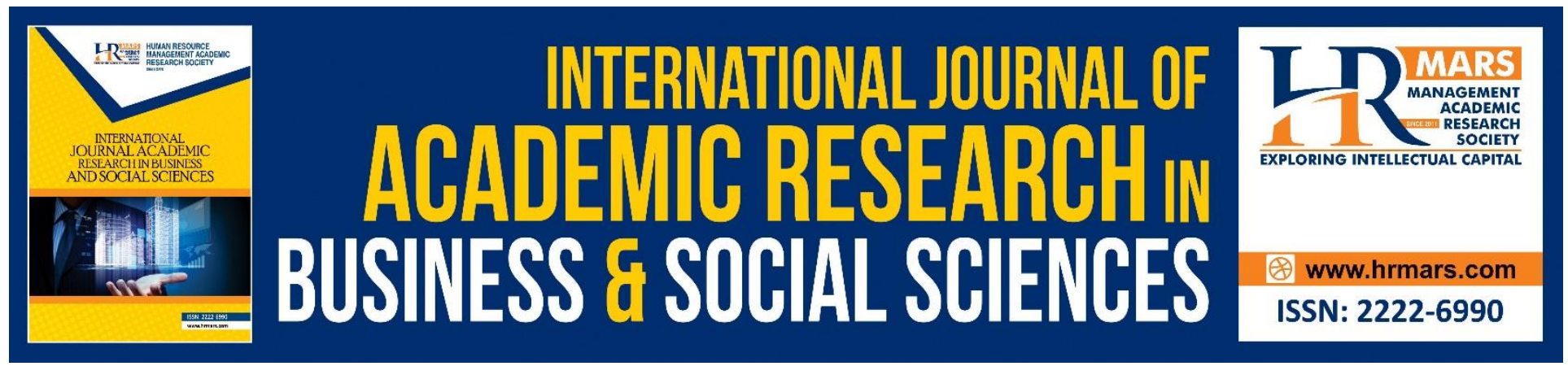

\title{
Problems Facing Urban Christian Church-Sponsored Schools Exemplified by St. Peter Claver's Catholic Primary School, Nairobi County
}

P. N. Wachege, Ng'etich K. Joel

To Link this Article: http://dx.doi.org/10.6007/IJARBSS/v9-i2/5532

DOI: $\quad 10.6007 /$ IJARBSS/v9-i2/5532

Received: 11 Jan 2019, Revised: 27 Feb 2019, Accepted: 08 March 2019

Published Online: 09 March 2019

In-Text Citation: (Wachege \& Joel, 2019)

To Cite this Article: Wachege, P. N., \& Joel, N. K. (2019). Problems Facing Urban Christian Church-Sponsored Schools Exemplified by St. Peter Claver's Catholic Primary School, Nairobi County. International Journal of Academic Research in Business and Social Sciences, 9(2), 175-189.

Copyright: @ 2019 The Author(s)

Published by Human Resource Management Academic Research Society (www.hrmars.com)

This article is published under the Creative Commons Attribution (CC BY 4.0) license. Anyone may reproduce, distribute, translate and create derivative works of this article (for both commercial and non-commercial purposes), subject to full attribution to the original publication and authors. The full terms of this license may be seen

at: http://creativecommons.org/licences/by/4.0/legalcode

Vol. 9, No. 2, 2019, Pg. 175 - 189

http://hrmars.com/index.php/pages/detail/IJARBSS

JOURNAL HOMEPAGE

Full Terms \& Conditions of access and use can be found at http://hrmars.com/index.php/pages/detail/publication-ethics 


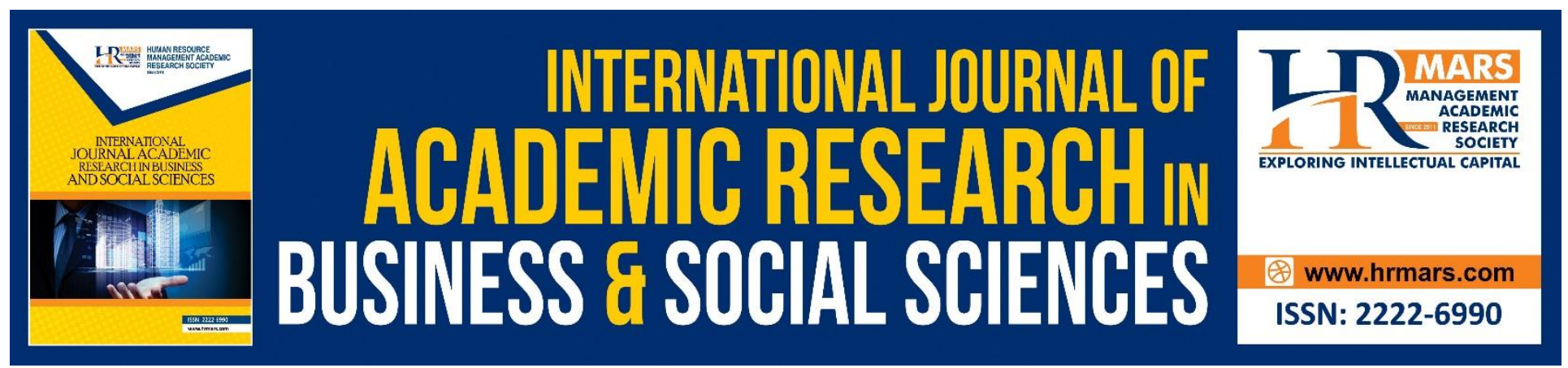

\title{
Problems Facing Urban Christian Church-Sponsored Schools Exemplified by St. Peter Claver's Catholic Primary School, Nairobi County
}

\author{
Prof. P. N. Wachege \\ Department of Philosophy and Religious Studies \\ University of Nairobi \\ Email: patricknwachege@gmail.com \\ Ng'etich K. Joel \\ Department of Philosophy and Religious Studies \\ University of Nairobi \\ Email: kipkiruinj@yahoo.com
}

\begin{abstract}
Education is one of the major social pillars that the National Strategic Plan captures in Kenya Vision 2030. Besides the government which is a main provider of education in the country, there are other partners such as the Roman Catholic Church that pursue the goal of providing holistic education. It is worth appreciating that, in Kenya, it is in common domain that the RCC has contributed a lot towards socio-political, economic and education growth. Nonetheless, efficiency and conflict of interest regarding management of some public sponsored schools together with mutual hostility with civil authorities more so in urban ones deserves critical attention. This provides a springboard for the study to investigate pertinent problematic factors that hinder the actualization of the ideals of Church sponsored urban schools in schooling and education focusing on St. Peter Claver's Catholic Primary School in Nairobi as a model.

The study applies qualitative research while using a case study design to collect data from both secondary and primary sources. Primary data is acquired through questionnaires, in-depth interviews, focused group discussions and observation. To delve further into the problem, the study is guided by three inter-dependent theories. They are: Social Learning Theory, Mediation Theory and Redaction Criticism Theory. The findings of the work include - but are not limited to - conflict between ecclesial sponsors and civil authorities, diverging faith affiliation demands, infrastructural problems together with environmental challenges. It is against these socio-economic milieus that the study articulates on the critical roles of the government and the Church as a sponsor to avert recurrent conflict of
\end{abstract}


interest and other problems that urban Christian Church sponsored schools face. In view of these issues a study on the problems facing sponsored primary schools is pivotal since the education received in these schools is the foundational level that determines most the present and future character of the pupils and school management, and guarantees upward mobility in schooling, education, and gainful employment.

Keywords: St. Peter Claver's Catholic primary school, Christian church-sponsored schools, urban, conflict of interest in schools.

\section{Introduction}

Among the mainstream Christian churches, the RCC is one of the oldest in Africa which committed herself to preaching a holistic Gospel through education and other socio-religio-economic and cultural means. The Church realized that schooling and education is the backbone of the wellbeing and development of any society playing a pivotal role in a much needed holistic development of humanity from their foundational stage to maturity. Missionaries used education as among the vital tools for evangelizing Africans that complemented preaching. The underpinning and driving factor behind the establishment of schools was to fulfill the biblical demand of living life fully (Jn 10:10).

The Church in Kenya, and in particular RCC, has principally partnered with the government not only in implementing education policies but in contributing towards educational reforms. Immediately after attaining independence in 1963, the government of Kenya charted a clear trajectory to meet education goals which culminated in a series of education reforms with a view of improving education standards and up scaling development in the country and realizing people's potentialities (Ominde Commission Report, 1964). The Catholic Church she has immensely contributed towards education development as a sponsor starting from the foundational level of primary school to university level across geographical spread. It-runs both private and sponsored schools in a concerted effort with the government and in the process it has readily prepared and released some of its gifted clergy to be full time teachers, lecturers and professors in public schools, colleges and universities. Despite the above, an observer will be quick to notice disturbing conflict between ecclesial sponsors and civil authority together with intra-rivalries, which could be just the tip of the iceberg (KCCB, 2003). This hinders the realization of schooling and education thereby creating a need to be researched upon at the level of erudition.

In Kenya, the phenomenon of education sponsorship is a concept that was coined during the government initiated Ominde Commission (Education Report of 1964) appreciating the education role of the Church to the community. Among the many fundamental schools established by the RCC using this model is St. Peter Claver's Primary School in Nairobi County. It is a public school established and sponsored by the RCC under St. Peter Claver's Parish in Nairobi Archdiocese. The school has a rich history right from the inception of St. Peter Claver's Church through Holy Ghost Fathers (HGF). It is strategically located at the heart of the populous city of Nairobi which has a diverse population of 3.13 million people (KNBS, 2009). There are over 2000 education institutions in Kenya as stipulated by Kwanya in Kenya Catholic Church Bishop report on Faith and Sustainable Development Goals in Catholic Church in Kenya: Long Term Plans 2015-2025, 113). One would be held aback to note that some of such public Church sponsored schools and civil authorities undergo acute relational problems 
that require urgent attention for a more significant contribution and relevance in view of contemporary milieu (Mabeya. et. al, 2010: 36).

\section{Research Issue}

It is enshrined in the constitution of Kenya (2010) Section 4, clause 53, that every child has a right to access quality education. This implies that, the aforementioned rights weave through all cadre of life regardless of the social standing in the society. It is arguable that the kind of educational foundation given to children whether formal or informal has had far reaching implication in the entire life. Their thought form and worldview is shaped by their early life experiences.

The input of the Church, more so, the RCC into education management and development cannot be gainsaid. For instance, their invaluable collaboration during policy making and education reforms from Ominde Commission (Ominde Education Report, 1964) to Koech Commission (TIQET 1999) has borne fruits. Ominde Report articulated that prior to independence, although the missionaries had established schools, their professionalism, standards, uniformity and expertise were inadequate. They used ill trained personnel and their curriculum was predominantly religious in outlook. To bridge the gap, the commission recommended the distinct roles of the government and the Church. The Church retained the role of the sponsor. The identity and tradition of the sponsor were fundamentally upheld. For a Church to qualify and retain the sponsor role, they need to demonstrate that they are capable of providing infrastructure and spiritual nourishment to the school pupils and quality representation in management.

The progress of the public Church sponsored schools were embedded on Christian values and more importantly hinged on the mutual nexus between the sponsor and the government. However, despite all the milestones on educational establishment, progress and management of schools, input by the sponsoring Church and the government as partners, the system is not devoid of existential management conflicts and infrastructural issues that have had far reaching implications on the character formation of the pupils at the foundation of their social and academic life (Cheruiyot, 2001). The difficulties are also pronounced even at the foundational level of education across rural and urban schools (Mabeya, et. al, 2010; Lugulu, 2013). These then call for deserving attention in the course of the study the paper opted for.

\section{Related Literature from Scholars}

This section seeks to address scholarly work of various selected authors to identify possible gaps.

A book by Sobrino's titled Jesus the Liberator: A Historical-Theological Reading of Jesus of Nazareth (Sobrino, 2001: 1ff) has been of immense value to this study. It underscores the concept and value of liberation in line with Jesus Christ as the Liberator par excellence even in matters of pedagogy. The author highlights the inhuman and anti-Christian oppressions that have been orchestrated for centuries without Christology raising its finger or providing any prophetic denunciation against the vice or even educating people to emancipate themselves and live in freedom (Sobrino, 2001: 3ff). He explicates further that Christology provide a way forward in the midst of all challenges that make people reflect on their situations and do something about it. 
In reference to I Peter 3:15, Christians furthermore are explicitly reminded to give reason for the hope that they have. It is on this perspective that Sobrino reignited the spirit of Christ's presence in Latin America and to put forth Jesus on the standpoint of liberation. The book enhances the study by underlying the significance of Christology in liberation of the society through education in particular. He offered a classic articulation of the role of Jesus Christ from a Latin American perspective and used Jesus as model Liberator even in pedagogy. The society under our study is facing poverty problems in the face of saturated Christianity. Although Sobrino's book articulates Christology as the exemplar which can be borrowed in the context of our study, he does not address the concept of liberation in particular learning institutions as we do but he is rather general. Despite the fact that the author's liberation concept can be applied across all aspects of life, the specificity on management of education to liberate the pupils from ignorance and acquisition of knowledge is missing. This study then endeavored to fill the missing gap

Another book that is of great value to the study is Freire's namely Education for Critical Consciousness (Freire, 1994: vii). His critical consciousness is multi cultural educator with rationally on the world and at the same time emotionally Brazilian context. In his view, he critically observes the nexus between oppression in various settings and the liberation outcome of conscientization. Freire underscores consciousness as the impetus of the cultural emancipation. As such, his work is fundamental towards creativity in education as a practice of liberation applicable to our study area too which requires to be emancipated from socio-economic-religio-political factors. It is fundamental to emphasize that without education the society cannot transcend to an open society (Freire, 1994: 7). After all is said and done, education is key to freedom. However, although Freire's work helps us to conscientize primary Church school sponsors, he emphasizes on the adult literacy. It would be more impactful in the society if the author begins conscientization from primary school. Such is the gap and the task in which our study complements it.

The study will benefit from, (Wachege, 2003: 225), comprehensive ideologies and way forward for the single mothers and widows in the society. Most of the single mothers bring up their children all by their own. The relevance of the book to the single mothers and widows in the school catchment areas of Landimawe, Muthurwa, Shauri Moyo, Majengo and Kamukunji cannot be over emphasized. Nevertheless, although the book identifies categories, causes, traditional views and Biblical perspectives on Single mothers and widows in the society, the book does not address the critical role and challenges of single mothers and mother widows on education. The evident gap on the challenge of raising and educating their children single handedly deserves attention. Children of single mothers, particularly commercial sex workers face a lot of stigma in school. Other categories of pupils that encounter psycho-social challenges are the orphaned children that are raised by grandmothers.

In her quest for moral ethical issues and knowledge addition that touched on the nerves of the African Education, Kinoti explains that prior to the coming of the colonialists and Christian Missionaries to Africa, Africans traditionally had their own methodology of educating and instilling values in the hearts of their youths. She underscored that, education in traditional Africa aimed at producing persons who upheld the values that helped the society to remain integrated (Kinoti, 2003: 80). 
Pragmatically, the book will aid the paper in highlighting the role of traditional teaching in imparting values and character formation that should reflect in our modern schools. Africans were given skilled based education to provide labor for the colonialists, Asians for business in the interest of the colonialist's progress and exploitation and the superior education to the white was meant to control the rest of the races. According to Wachege's CRS 560, this did not augur well in light of the concept on African worldviews items (Wachege, 2012, CRS 560: 14-21). It is no doubt that in Africa worldview are underscored as follows: Vitality, dynamism, sacrality, communalism and anthropocentrism.

In study similar to this (Lugulu, 2013) observes that disputes between Ministry of Education and Church-sponsors over management and administration of the schools is not something new. In a dialogue with the study, it is explicit that the conflicts have had far reaching implications and have detriment effects on the academic and social progress of the students. Evident interruptions and at worse is the closure of the schools when such conflicts arise. Further, the study argues that conflicts cause uncertainties, and interference of the school program. Although this study is valuable, it nevertheless addresses itself to the challenges of the high school and not primary schools. There is a gap in addressing the primary school challenges which is the foundation of all learners.

Magesa in Christian Ethics in Africa provided a synopsis of the Christian pragmatic life. Two things are outstanding in his book: 1) The ethics of liberation and 2) Christ as a valuable agent of liberation as a liberator (Magesa, 2002: 36f). It is arguable that the Western scholars have often addressed the ethical issues from the individualistic orientation. Magesa on the other hand addressed the issue of Christian ethics from the African orientation-the communalistic approach. He viewed Christ as a liberator in the lenses of the African situation. The pragmatic approach used by Jesus to all individuals and the society ought to be upheld. To him all were ethically called to freedom regardless of the class, color, race, location or ability. He added that Jesus gave hope to the suffering, exploited and restores the dignity of the downtrodden. This book assisted the study for excavating ethical barriers, behavior exhibited by the Church leadership as a model and agent of liberation.

Although the author addresses the ethical values in African context, he acknowledges that the Church failed to address and provide justice as a social teaching in the church ((Magesa, 2002: 47f). Africa had her own way ways of imparting knowledge when the Church may not address. Despite all the much applauded and articulated African values, the author did not address the issue of who and how the values must be inculcated to the pupils in modern western schools. Today, it is evident that there is a deficiency of ethical values both in schools and in the society. Indirect slavery and stratification of the society into classes is not something new. There is rampant burning of schools; mismanagement of resources and social crimes in the society just to mention a few yet the author does not give any mitigating measures.

Njoroge and Bennaars (1986: 30-32), in their published book on Philosophy of Education in Africa contributes significantly toward the development of this study. The authors accentuated vividly on the philosophical approach to education in a general and technical sense. The broad and specific understanding and doing education particularly in the African world view is given prominence. The book adds an immense value to the study particularly on meaning and methodology. However, the 
gap is on how the management of the same education whether in the Western or Africa is not addressed. The study fills up the lacuna by more exploration on the management of which various stakeholders will make an input for the success of education even at the foundational level.

Okumbe (1998: 11ff) is intended to shape the managers of education into prudence and produce reliable educational product. The book articulates on management of resources and desired relations with other stakeholders of education. In light of the said best management practices for results in institutions, Okumbe envisages in his writing that efficiency on management is key to quality and is viewed from internal and external perspective. The author is elaborate in spelling out that it is not enough to put education policies in place, but the pragmatic approach to education is fundamental. Although the author has articulated well the theoretical and practical approach to management of the school, a synopsis of the book shows that the author took the line of professional managers and to the advantage of scholars and students of education. However, management of the school entails a whole host of stakeholders. Church-sponsors, community and the Ministry of education are also directly involved in the management of school. Even-though all these are not concerned with the daily running of the schools, the author ought to have addressed their input as far as the management of the school is concern. Our study sought to bridge education management gap.

In their wisdom and passion for education and history, (Sifuna and Otiende, 1992: 3), acknowledge that reflecting on the history is essential for the present and the future. They give a narrative that is punctuated by education policies and reforms that necessitate progress and efficient, quality education in Africa. These sentiments are also underscored by Bogonko, 1992: 2). The emphasis on this is the categorical roles of the civil authority and their education partners (church-sponsor) are vividly addressed. Nonetheless, the challenges experienced by the religious and in particular Christian sponsors in education are not postulated yet they are vital in the education journey as the study shows.

\section{Methodology}

The study is guided by the following three theories: Social Learning Theory, Mediation Theory, and Redaction Criticism.

The Social Learning Theory propagated by Bandura addressed itself to fundamental number of ideal approaches to learning environment of St. Peter Claver's primary school. The theory advocates that people learn through observation, imitation, and modeling which was instrumental to the study. It resonates well with the pupils who look up to their leaders, educators included, as role models in the society. It cannot be gainsaid also that all players in the education sector have had an opportunity to learn from one another via observation, conservation and imitation in knowledge addition and decision making.

Mediation Theory as given by Boff and Boff gave the work an impetus through three important methodological aspects: socio-analytical aspect, hermeneutical aspect and the practical aspects (Boff \& Boff, 1987: 24-39). Socio-analytical mediation aided this work by enabling the researchers to inserting themselves into the situation to experience and retrieve vital information on the ground in relation to the chosen area of study. Besides that, hermeneutical aspect engages the collected data to ascertain the will of God in the Bible and tradition regarding St. Peter Claver's Catholic primary 
school and it's environ. Lastly, the praxis entails moving into action to emancipate the society from social oppression. The importance of the praxis aspect is a purposeful action to emancipate the society from socio-economic and managerial problems in reference to urban Schools' ecclesial sponsorship. This inspired the way forward in a bid to stem the problems identified during socioanalytical aspect.

The third theory, Redaction Criticism Theory (Collins, 1983: 196-198), assisted in sourcing relevant and authentic Biblical Scripture that addressed the pertinent problems in the society. Besides sourcing, the theory aided in getting the glimpse of the author, preferences, audience and the entire context in which that scripture was used. It is viewed with care in this milieu that the theory aided the researcher to draw authentic scriptures from the erudition level for the sole purpose of addressing the problems facing St. Peter Claver's Catholic Primary School.

This was qualitative research that utilized descriptive case study design (Kothari, 1985: 37) and as used by Ozo and Owen (2009: 37) echoed how research used descriptive design to present phenomenon as they are. A sample of 67 was drawn from school administration, teachers, selected pupils, parent representatives, clergy, representatives from Ministry of Education and Archdiocese of Nairobi. The research utilized purposive sampling and snowball methods. Data was collected from 30 selected pupils from class seven and eight; 10 parents, 10 teachers, 5 St. Peter's Parish clergy, 3 Archdiocese of Nairobi, 6 school administrators and 3 representatives from the Ministry of Education. The study used questionnaires and structured in-depth interviews together with focused group discussions. It is worth mentioning that the validity and the reliability of the questionnaires were put to test through administering to colleagues and the supervisor for further verification.

\section{Findings}

The study unveiled several outstanding problems encountered by St. Peter Claver's Catholic primary school. For specificity sake and within the confine of the paper, we herewith indicate the fourfold main impeding problem that emerged from the study. They are briefly expounded as: diverging faith affiliation demands, infrastructural problems, environmental challenges together with perennial conflict of interest between ecclesial sponsors and civil authorities.

\section{Diverging Faith Affiliation Demands}

One of the major concerns facing the school is religious pluralism. It emerged that although the world has positively embraced inter-faith dialogue, it is not lost to our observation that individual religious adherence is fundamental to maintain one's faith identity. Religious terrain has changed drastically where everyone is accommodated as part of the basic human right. Religious diversification becomes a big issue when it takes a negative twist of exclusion and isolation. Although the sponsor does not discriminate on any students or teachers from any other denomination, the problem remains that all must comply with the standards and tradition of the school sponsor. Those who do not subscribe to the faith affiliation do not have an alternative but to comply for the sake of education and work.

Pupils who hail from other denominations such as Pentecostal, Anglican Church of Kenya, Seventh Day Adventist Church and Akorino and other Africa Instituted Churches may not be conversant with the RCC liturgy although they are not compelled to attend Mass but they are disenfranchised on religious practice. The identity and tradition of RCC is the in thing within the school. The basis of the 
argument is that those who join the school already knew the sponsor as RCC and their expectation (Interview by author: 2017). Nonetheless, in a situation where the Kenyan Constitution (2010) guarantees freedom of worship and association, the bone of contention is how to accommodate diverse faith affiliation without injuring the religious freedom while at the same time respecting the identity, discipline and belief socialization of the sponsor. In this scenario the study found out that non Roman Catholic pupils feel disenfranchised and their spiritual needs are not catered for.

\section{Infrastructural Problems}

The study established that St. Peter Claver's Catholic Primary School sits at a prime place within the city centre. Evidently, to acquire so much acreage at such a place is a rare opportunity. The early missionaries who founded the school were indeed far sighted. It therefore means that to maximize such a space which is predominantly a business centre calls for proper and professional planning. It was observed that classrooms and administration block are as old as the inception of the school though surrounded by huge upcoming modern commercial buildings. That notwithstanding, it is admirable that these buildings bring in nostalgic memories, history and identity mainly on the issue of RCC missionaries option for founding schools as important means for a holistic evangelization. However, with the increasing population and shrinking space, modern architectural and environmental friendly buildings are needed. The scattered buildings may have suited the environment then but in the $21^{\text {st }}$ century going forward proper utilization of the space is ideal for the good of the pupils and the management.

It is evident that the government may build through Community Development Funds (CDF) or any other grants: however, the sponsor has a major role to play in Christian Church sponsored schools. The study then found out that the school suffers infrastructural challenges since the government capitation is not enough to improve the conditions of the school. The administration in this case had to be creative in sourcing for funds particularly to put up a perimeter wall which posing security risk to the pupils and staff. It was observed that, since the school is a public school, the Church sponsor is not investing much on infrastructure, hence the poor state of buildings and the compound that require massive infrastructural change.

\section{Environmental Challenges}

Morally and legally, the government is vested with the duty and responsibility of ensuring that their citizens enjoy work and good living environment. The school going children who are in their tender ages are susceptible to diseases and therefore body immunity is a priority to avert present and future health hazards.

St. Peter Claver's Catholic Primary School is strategically located within the City of Nairobi in an enviable locality whose land value is bid pecuniary. The Church is sandwiched between the busy Race Course Road, Haile Salaisie and Landies Road, which is a problem by itself among young school going children. Pupils from the surrounding environs and parents who work within the City enjoy the convenience of dropping and picking their children in the evening despite the human and traffic jam. The intention of the sponsor to establish a school was driven by a benevolent spirit of serving the hitherto communities. 
The study established that among the serious developmental worries encountered by the school is intense noise, air pollution (carbon emission), dust from within a bare compound and without and foul smell from the neighborhood of wakulima market. As eluded above, dust is a menace that has far reaching implication on the health of the pupils and staff. The compound is bare and dusty. This is exacerbated by the huge human population and many cars in the compound which constantly raise dust which apart from impeding studies are is a health hazard to pupils, teachers and staff. When the dust settles in class it affects vulnerable children particularly those with weak immune system. To add salt on top of an injury, majority of the pupils come from the poor families that hardly access a balance meal if ever they get one. As a result, their immune system degenerates Although the school has tried to raise the perimeter wall to avert noise from the rowdy matatu (public transport vehicles). It does not prevent the flow of the huge amount of dust into the compound. The study revealed that coughing, asthma and such air-born ailments are common here.

As if that is not enough, matatu drivers keep hooting and calling for their clients along the busy Race Course Road with music playing full blast. The matatu terminus is set right at the gate of the school where passengers are dropped and picked. The National Transport and Safety Authority (NTSA), a legal body entrusted with road safety in Kenya, has neither put any warning sign on the speed limit of $10 \mathrm{KPH}$ nor a No Hooting order at the gate. In addition to the noise, the shrilling sound from the same matatus is too harsh for the young learners. The trending design is invested on the huge speakers that produce loud music and their exhaust pipes are fitted to give a unique matatu sound identity. This has a huge impact on the learners on their listening capacity and performance.

Another risky and hazardous pollutant is the constant emission of carbon from the countless vehicles around the school which is extremely injurious. The danger that comes with this emission is the consistent inhaling by the pupils and the teachers. The amount inhaled daily may seem negligible but over time it accumulates and the end result are complex diseases. Nonetheless, all these occur not because there are no clear stipulated policies, but lack of enforcement. Where the policy is weak or has been overtaken by events, it requires amendment. Corruption in the society has eroded values thus creating a culture of negligence of the vulnerable children in the society as alleged by one of the observer who has works as a cart puller for many year along the Race Course Road. Evident impunity in the matatu sector has consistently led to ignoring National Environment and Management Authority (NEMA) directives on prohibition of loud noise beyond 30 decibels (National Climate Change Action Plan, 2013-2017: 68-69).

St. Peter Claver's Primary Catholic School is adjacent to the famous and busy Wakulima market of Muthurwa. In the market there is poor waste disposal and foul smell from decomposed products which are rarely collected. In addition to that there are broken sewer pipes thus exposing raw sewage which is a recipe for health hazard that may spread diseases like cholera, malaria and typhoid. All these affect pupils during their time in school or out of school. According to Pope Francis's Encyclical letter titled Laudato Si $(2015$, No. 1), the Pontiff underscores that the Christian Church is also concerned about our common home, that is our planet earth given to us by God in trust.

\section{Conflict Between Ecclesial Sponsors And Civil Authorities}


It suffices to appreciate that the government and the Church sponsor are key stakeholders on education development of the country. This arrangement is geared towards a holistic development of the learners. However, to get the gist of this development, the study delved into accentuating the role interface of the sponsor and the government. Drawing from the rich history predating independence in 1963, some of the convergent roles have been the mutual contributions during education reforms in the country. The government is mandated by law to manage education through legally established bodies such as Teachers' Service Commission, Kenya National Examination Council and Kenya Institute of Curriculum Development. Each one of them has a critical role towards education development in Kenya that must work in harmony for the good of the individuals and the society. On the other hand, the role of the Church sponsor is stated categorically in (Basic Education Act 2013, section 27). They are enumerated as physical infrastructure, spiritual guidance and counseling, representation, partnership with the government and monitoring education progress in the sponsored or private schools.

The study established that the perennial tension of who has control over the school management between the civil authority and the Church does exist and hurts development of the school. Despite distinct roles of the sponsor and the civil authorities, the school has been affected by unfair competition and overlapping of the responsibilities. The head teacher is forced to go an extra mile looking for resources to development the school yet the onus rests squarely on the shoulders of the sponsor. The study found out that by virtue of the church owning the school as sponsors without putting in substantial resources hurt the management of the school. The annual capitation from the government does not either give the government to exercise their prowess over the sponsor. These conflicts hamper management and development of the school socially, academically and economically. The intention of controlling school resources without investing in it significantly has exacerbated managerial and administrative conflicts.

\section{Study's Implications}

St. Peter Claver's Catholic primary school encountered several problems ranging from divergent faith affiliation demands, infrastructural problems, environmental challenges and conflict between ecclesial and civil authorities that have had direct or indirect impact on management and development of the school. The specific implications are stipulated as follows:

6.1 The school understudy is a public school that is sponsored by Roman Catholic Church; however the school admits pupils from divergent faith affiliation. The study found out that all students and teachers alike have to abide by the traditions and faith affiliation of the school sponsor. The implication of these shows that the rest of the faith affiliate pupils and staff feel disenfranchised since they are not versed with the Catholic tradition. Most of them were not brought up in the culture and traditions of the RCC and this has a great impact in the faith. Some of the affected individuals claimed that they attend mass only as a formality of which this has a huge dent in their spiritual life now and in future.

6.2 The infrastructure of the school is as old as the inception of the school. The evident laxity on the improvement of the infrastructure has hampered the expansion and modernization of the 
school infrastructure. The annual capitation from the government is not enough to develop the school while the Church sponsor has not done any better to alleviate the problem. This implies that the scattered buildings and dusty compound is not a reflection of the image of a modern school within the city centre. Although the Education policy 2013 stipulates clearly on the mandate of the sponsor on infrastructure, it is evident that the church has absconded their responsibility on investing in school. The government annual capitation is not enough to improve on the infrastructure.

6.3 It is no doubt that the environmental problems have had far reaching health implication on the learners and the staff of St. Peter Claver's primary school. The study observed that the implication of interference from the noise and air pollution poses a health hazard to the pupils and the staff is acute. It is against this backdrop that the government, Church sponsor, parents and school management have a huge and taunting responsibility of mitigating the effects of the environmental problems to secure and guarantee health safety and conducive learning environment now and in the future.

6.4 Perennial conflicts of interest between the government and the Church sponsor have led to low performance of the school. It is observed that both partners claim ownership and legitimate control over the school. The roles overlap without much input into the school impacts negatively on the management and administration of the school. The implication of this conflict of interest has ignited the desire among the Church sponsors of reverting the school from public to private for effective management from the sponsor's perspective. The school experience setbacks as a result of the grey area or negligence from one partner. The quest for managing the available resources has exacerbated tension hence church's decision to consider fast tracking reverting the school to private ownership in order to transform it into a high performing school (Parish Strategic Plan, 2012-2016: 52).

\section{Conclusion and Recommendations}

This study investigated the problem facing urban Christian Church sponsored schools particularly in St. Peter Claver's Catholic primary school in Nairobi County. It is no doubt that apart from the government's role as the provider and manager of education in Kenya, the Christian Church's role cannot be understated. Despite the church's immense input into establishment and management of the education ranging from primary level to university levels; it is observable that St. Peter Claver's primary school is faced with numerous challenges. The study underscored the findings as diverse faith demands as a result of religious pluralism, infrastructural challenges, environmental problems and perennial conflict of interest on management and administration of the schools. Besides all these challenges, there are prudent methods and strategies in place to address these emerging education sponsorship conundrums. Church sponsors have tremendous responsibilities to invest in public sponsored primary school just like any other private schools and alleviate them from pathetic infrastructural situations, rethink and respect diversity of faith and insulate the school form environmental hazards. However, over relying on the capitation from the government and Community Development Fund (CDF), undermines their stipulated roles on management of the primary school. Although the government has an input on the development of the church sponsored 
school, the onus is on the church sponsor to invest meaningfully and minimize the perennial conflicts between the government and ecclesial authorities for better management outcome.

The following recommendations then are inspired by the study:

i) Reassessing the role of the sponsor's religious tolerance, inclusivity, identity and freedom of other adherents.

Basic Education Act 2013 underscores the responsibility of the sponsoring Church to manage spiritual nurture of the pupils and staff of the school. In light of religious pluralism and diverse faith affiliation, it is recommended to allow various adherents to practice their own faith practices without injuring on the faith and dignity of the sponsoring church.

ii) The church-sponsor ought to play their rightful role of investing on the school infrastructure for better results.

The study recommends the school sponsor to invest in the school to improve the infrastructure of the school. The Parish in Church should reassess, redesign and invest significantly on infrastructure as part of their responsibility. In addition to that, re-carpet the school compound to avoid dust, reduce the number of vehicles parked in the school compound and lobby the government to reduce noise and air pollution from matatus.

iii) Addressing environmental challenges

The environmental condition of the school both internally as a result of dust and external as a result of carbon emission and acute noise from matatus need to be addressed with urgency. The study recommends that the Church sponsor should build ultra modern buildings that are noise proof and dust proof. In addition to that, plant trees strategically and reduce the number of vehicles parked within the compound. Along with that, it is worth reflecting that schools, other than dealing with children academically, also complement the parents in training well behaved children, and in that case and as Wachege and Rugendo (2018) found out that the school environment should be supportive of holistic teaching of children.

iv) Redefining Education Policy on School Management to avert conflict of interest. A critical look at Basic Education Act 2013 and the Policy Document for Catholic Education in Kenya 2013 shows a whole raft of roles and expectation of education partners are adequately addressed. Well articulated policies and procedures are in place as required, however, the mode of implementing education policies is one thing. From the findings, the sponsor is awakened to take up their rightful position and fulfill their obligation while the government should streamline the policy issues and administration. The Church has a right to revert the public sponsored schools to private ones for efficiency and productivity. This is in tandem with its strategic plan of the school which desires on reverting the school for quality management and averts conflict of interest, enhance proper management and infrastructural input. (Parish Strategic Plan 2012-2016). This will restore the dignity of the Christian sponsored primary schools and the Church sponsor. It is therefore recommended that the partners should revert public sponsored schools to private owned school for better management, quality resourced and better performance of the pupils.

v) Mutual partnership with other stakeholders 
The school sponsor may not be able to deliver on many demands on their own without the assistance of other valuable stakeholders. It is recommended then to call for mutual partnership with the ecclesial authority, County Government, business community, parents, community and well wishers with a view of developing the school infrastructure.

Areas for further research

The focus of this study was St. Peter Claver's primary school as a case study; however, further research can be done on similar schools both in urban informal settlements and rural schools since they have unique challenges. In addition to that, further research can be done on the socio-economic impact on debunking church sponsored school and reverting to private schools.

\section{Corresponding Author}

$\mathrm{Ng}$ 'etich K. Joel,

Department of Philosophy and Religious Studies

University of Nairobi, Email: kipkiruinj@yahoo.com

\section{References}

Bandura, A. (1977). Social Learning Theory. New York: General Learning Press.

Boff, L. \& Boff, C. (1994). Introducing Liberation Theology. Maryknoll, New York: Orbis Books.

Bogonko, S.N. (1992). A History of Modern Education in Kenya (1895-1992). Nairobi: Evans Brothers Kenya.

Collins, R. F. (1983). Introduction to the New Testament, London: SCM Press.

Dupuis, J. (1997). Toward a Christian Theology of Religious Pluralism, Maryknoll, New York: Orbis Books.

Dupuis, J. (2002). Christianity and the Religions: From Confrontation to Dialogue, Maryknoll, New York: Orbis Books.

Francis, Pope. (24 May, 2015). Laudato si, Vatican, Rome.

Francis, Pope. (24 November, 2013). Evangelii Gaudium, Vatican, Rome.

Freire, P. (1998). Education for Critical Consciousness. New York: Continuum.

Kenya Conference of Catholic Bishops. (2013). Policy Document for Catholic Education in Kenya. Commission for Education and Religious Education. $4^{\text {th }}$ ed. Nairobi.

Kothari, C. R. (1985). Research Methodology: Methods and Techniques, ( $2^{\text {nd }}$ Edition), New Delhi: New Age Publication (Academics).

Kwanya, C. O. The Kenya Conference of Catholic Bishop, "Faith and Sustainability Development Goals: Catholic Church of Kenya-long Term Plan 2015-2025" Nairobi.

Mbiti, J. S. (1990). African Religion and Philosophies. Oxford: Heinemann.

Moltmann, J. (1964). Theology of Hope. Maryknoll, New York: Orbis Books.

Mugambi, J.K.N. \& Nasimiyu-Wasike, A. (2003). Moral and Ethical Issues in African Christianity. Nairobi: Acton Publishers.

Mugenda, O. \& Mugenda, A. (2003). Research Methods: Quantitative and Qualitative Approaches. Nairobi: ACT Press.

Nairobi City County. Nairobi County Integrated Development Plan 2014. Nairobi: Government 
Printer.

Njoroge, R. J. \& Bennaars, G. (1986). A Philosophy of Education in Africa. Nairobi: TransAfrica Press.

Ochieng'-Odhiambo, F.A. (2009). A Companion to Philosophy. Nairobi: Consolata Institute of Philosophy Press.

Francis, P. (2015). Laudato Si. Nairobi: Paulines Publications Africa.

Republic of Kenya. Education Commission Report. (Ominde Commission 1964). Nairobi: Government Printer.

Republic of Kenya. Kenya Vision 2030. Nairobi: Government Printer.

Republic of Kenya. Recommendation on Totally Integrated Quality Education and Training (TIQET). (Koech Commission Report 1999): Government Printer.

Republic of Kenya. The Basic Education Act 2013. Nairobi: Government Printer.

Sifuna, D. N. \& Otiende, J. C. (1992). An Introductory History of Education. Nairobi: Starbright Services Ltd.

Sobrino, J. (1991). Jesus the Liberator: A Historical and Theological View. Maryknoll: Orbis Books.

St. Peter Claver's Parish Nairobi. (2012). Strategic Plan (2012-2016). Nairobi: Schema Services. The Constitution of Kenya. (2010). Revised Edition. Nairobi: The National Council for Law Reporting.

Wachege, P. N. (2003). Third Millennium African Single Mothers and Mother Widows: EthnoReligio-Philosophical Touch. Nairobi: Media Options.

Wachege, P.N. (2012). CRS 560: African Christian Theology. Nairobi: University of Nairobi. 